\title{
PROSES ADMINISTRASI PERKARA PIDANA DALAM PENYELESAIAN PERKARA PIDANA DI PENGADILAN TINGGI JAMBI
}

\author{
Oleh : \\ Hendri Fakhruddin * \\ Ferdricka Nggeboe *
}

\begin{abstract}
ABSTRAK
Lembaga peradilan sebagai lembaga penegakan hukum dalam system peradilan pidana merupakan suatu tumpuan harapan dari para pencari keadilan yang selalu menghendaki peradilan yang sederhana, cepat dan biaya ringan sebagaimana yang diatur dalam Pasal 2 ayat (4) Undang-Undang Nomor 48 Tahun 2009 tentang Kekuasaan Kehakiman. Putusan hakim atau putusan pengadilan merupakan aspek penting yang diperlukan untuk menyelesaikan perkara pidana. Dengan demikian dapatlah dikonklusikan lebih jauh bahwasanya putusan hakim disatu pihak berguna bagi terdakwa untuk memperoleh kepastian hukum (rechts zekerheids) tentang statusnya dan sekaligus dapat mempersiapkan langkah berikutnya terhadap putusan tersebut dalam artian dapat menerima putusan, melakukan upaya hukum verzet, banding atau kasasi. Cara kerja khususnya paa tingkat Banding di Pengadilan Tinggi Jambi ditemukan penegakan hukum pidana tidak dapat dilakukan secara total sebab dibatasi secara ketat oleh aturan hukum acara pidana dan hukum pidana substantif. Penegakan hukum pidana membutuhkan kinerja aparat penegak hukum bersifat progresifyaitu menegakkan hukum pidana dalam rangka mewujudkan keadilan, kesejahteraan dan kepentingan rakyat. Supremacy of law bukan diterjemahkan sebagai supremasi undang-undang, melainkan supremacy of justice. Yang diharapkan adalah cara kerja sejalan dengan tuntutan cara kerja aparat peradilan yang diamanatkan oleh Undang-Undang Nomor 48 Tahun 2009 tentang Kekuasaan Kehakiman, Pasal 5 ayat (1) bahwa hakim wajib menggali, mengikuti, dan memahami nilai-nilai hukum dan rasa keadilan yang hidup dalam masyarakat. Cara kerja seperti itu merupakan perwujudan birokrasi peradilan pidana berbasis pelayanan publik yang diwujudkan dalam bentuk pelayanan prima dan pelayanan sepenuh hati.
\end{abstract}

Kata Kunci: Proses Adminitrasi, Perkara Pidana, Pengadilan Tinggi

\section{A. Latar Belakang Masalah}

Penegakan hukum merupakan salah satu usaha untuk mencapai atau menciptakan tata tertib, keamanan dan ketentraman dalam masyarakat baik itu merupakan usaha pencegahan maupun pemberantasan atau penindakan setelah terjadinya pelanggaran hukum, dengan perkataan lain baik secara preventif maupun represif. Sejauh ini peraturan yang mengatur tentang penegakan hukum dan perlindungan hukum terhadap keluhuran

\footnotetext{
* Panitera Pengganti Pengadilan Tinggi Jambi, Alumni Program Magister Ilmu Hukum Unbari.

* Pengajar Program Magister Ilmu Hukum Unbari.
} 
harkat martabat manusia di dalam proses pidana pada hakekatnya telah diletakkan dalam Undang-undang Nomor 48 Tahun 2009 Tentang Kekuasaan Kehakiman dan UndangUndang Nomor 8 Tahun 1981 tentang Kitab Undang-undang Hukum Acara Pidana (KUHAP).

Lembaga peradilan sebagai lembaga penegakan hukum dalam system peradilan pidana merupakan suatu tumpuan harapan dari para pencari keadilan yang selalu menghendaki peradilan yang sederhana, cepat dan biaya ringan sebagaimana yang diatur dalam Pasal 2 ayat (4) Undang-Undang Nomor 48 Tahun 2009 tentang Kekuasaan Kehakiman. Keadilan yang dihasilkan dari suatu lembaga peradilan melalui suatu proses peradilan yang tertuang di dalam putusan hakim adalah merupakan syarat utama di dalam mempertahankan kelangsungan hidup suatu masyarakat sebab putusan-putusan hakim yang kurang adil membuat kepercayaan masyarakat terhadap lembaga peradilan menjadi berkurang, sehingga mengakibatkan masyarakat enggan untuk menempuh jalur hukum di dalam mengatasi permasalahan hukum yang mereka hadapi. Maka dalam hal ini hakim sebagai pejabat Negara yang diberi wewenang oleh undang-undang untuk mengadili dalam suatu proses peradilan pidana, mempunyai suatu peranan penting dalam penegakan hukum pidana untuk tercapainya suatu keadilan yang diharapkan dan dicita-citakan.

Penyelenggaraan peradilan pidana sebenarnya tidak hanya oleh hakim dalam suatu proses peradilan namun juga harus di dukung oleh aparat penegak hukum pidana lainnya yang tergabung dalam system peradilan pidana (Criminal Justice Sistem) yaitu Polisi, Jaksa, Hakim, dan Petugas Lembaga Pemasyarakatan yang bekerja mulai dari proses penyelidikan dan penyidikan, penangkapan, penahanan, penuntutan sampai akhirnya pada pemeriksaan di sidang pengadilan. ${ }^{1}$

Ketika seorang hakim sedang menangani perkara maka diharapkan dapat bertindak arif dan bijaksana demi untuk mendapatkan kebenaran materil yaitu kebenaran yang selengkap-lengkapnya dari suatu perkara pidana dengan menerapkan ketentuan hukum acara pidana sebagaimana yang tertuang dalam pasal demi pasal yang ada di dalam KUHAP guna menentukan apakah seorang terdakwa terbukti melakukan suatu tindak pidana atau tidak dan apabila terbukti bersalah maka seorang terdakwa tersebut dapat dijatuhi pidana atau sebaliknya bila tidak terbukti bersalah maka seorang terdakwa harus diputus bebas sehingga kesemuanya itu bermuara kepada putusan yang dapat

\footnotetext{
${ }^{1}$ Yesmil Anwar dan Adang, System Peradilan Pidana (Konsep, Komponen dan Pelaksanaannya Dalam Penegakkan Hukum Di Indonesia), Widya Padjadjaran, Bandung, 2009, hal. 28
} 
dipertanggungjawabkan baik dari aspek ilmu hukum itu sendiri, hak asasi terdakwa, masyarakat dan Negara, diri sendiri serta demi keadilan berdasarkan Ketuhanan Yang Maha Esa. ${ }^{2}$

Penegakan hukum pidana pada tahap ajudikasi (persidangan) menempatkan posisi penting karena pada tahap tersebut adanya proses pembuktian menurut hukum oleh hakim untuk menentukan apakah terdakwa bersalah dan dapat dihukum atas perbuatan yang didakwakan oleh jaksa penuntut umum kepadanya. Keputusan hakim tersebut harus berdasarkan fakta dan keadaan serta alat pembuktian yang diperoleh dari hasil pemeriksaan di sidang pengadilan.

Mekanisme pemeriksaan perkara pidana (birokrasi peradilan pidana) tersebut harus berdasarkan ketentuan hukum acara persidangan. Birokrasi peradilan pidana pada tahap persidangan diatur dalam Bab XVI dan Bab XVII mulai Pasal 145 sampai Pasal 258 KUHAP. Penyelenggaraan peradilan berdasarkan KUHAP tersebut berasaskan antara lain peradilan yang bebas, terbuka untuk umum dan dilaksanakan dengan cepat, sederhana, dan biaya ringan, serta bebas, jujur dan tidak memihak yang dilaksanakan oleh pejabat tertentu yang segala aktivitasnya diwujudkan secara tertulis berdasarkan perundang-undangan. Peradilan tersebut dilaksanakan dengan tujuan demi keadilan berdasarkan Ketuhanan Yang Maha Esa.

Oleh sebab itu, untuk mendapatkan kebenaran materil diatas maka hakim dalam mengemban tugas harus dijamin kemandiriannya guna menegakkan keadilan sebagaimana yang disebutkan dalam Pasal 1 Undang-Undang Nomor 48 Tahun 2009 tentang Kekuasaan Kehakiman bahwa kekuasaan kehakiman adalah kekuasaan Negara yang merdeka untuk menyelenggarakan peradilan guna menegakkan hukum dan keadilan berdasarkan Pancasila dan Undang-Undang Dasar Negara Republik Indonesia Tahun 1945, demi terselenggaranya Negara Hukum Republik Indonesia. Dipihak lain dalam diri hakim bersangkutan juga dituntut adanya integritas moral yang baik sehingga dalam menegakkan hukum dan keadilan tidak merugikan "justiabelen" (para pencari keadilan). ${ }^{3}$ sebagaimana yang diatur dalam Pasal 5 ayat (2) Undang-Undang Nomor 48 Tahun 2009 tentang Kekuasaan Kehakiman bahwa hakim dan hakim konstitusi harus memiliki integritas dan

\footnotetext{
${ }^{2}$ Waluyadi, Pengetahuan Dasar Hukum Acara Pidana(Sebuah Catatan Khusus), Mandar Maju, Bandung, 1999, hal. 15.

${ }^{3}$ Lilik Mulyadi, Hukum Acara Pidana (Suatu Tinjauan Khusus Terhadap Surat Dakwaan, Eksepsi Dan Putusan Peradilan), PT. Citra Aditya Bakti, Bandung, 2002, hal. 33-34.
} 
kepribadian yang tidak tercela, jujur, adil, professional dan berpengalaman di bidang hukum.

Kemandirian hakim adalah kemandirian dalam tugas dan wewenang dalam kapasitasnya ketika sedang menangani perkara, adapun wewenang hakim antara lain sebagai berikut

1. Untuk kepentingan pemeriksaan di sidang pengadilan, hakim dengan penetapannya berwenang melakukan penahanan (Pasal 20 ayat (3) KUHAP).

2. Memberikan penangguhan penahanan dengan atau tanpa jaminan orang, berdasarkan syarat yang ditentukan (Pasal 31 ayat(1) KUHAP).

3. Mengeluarkan Penetapan agar terdakwa yang tidak hadir di persidangan tanpa alasan yang sah setelah dipanggil secara sah untuk kedua kalinya, dihadirkan dengan paksa pada sidang pertama berikutnya (Pasal 154 ayat (6) KUHAP).

4. Menentukan tentang sah atau tidaknya segala alasan atas permintaan orang yang karena pekerjaannya, harkat martabat atau jabatannya diwajibkan menyimpan rahasia dan minta dibebaskan dari kewajiban sebagai saksi (Pasal 170 KUHAP).

5. Mengeluarkan perintah penahanan terhadap seorang saksi yang diduga telah memberikan keterangan palsu di persidangan baik karena jabatannya atau atas permintaan Penuntut Umum atau terdakwa (Pasal 174 ayat (2) KUHAP).

6. Memerintahkan perkara yang diajukan oleh Penuntut Umum secara singkat agar diajukan ke sidang pengadilan dengan acara biasa setelah adanya pemeriksaan tambahan dalam waktu 14 (empat belas hari) akan tetapi Penuntut Umum belum juga dapat menyelesaikan pemeriksaan tambahan tersebut (Pasal 203 ayat (3) huruf b KUHAP).

7. Memberikan penjelasan terhadap hukum yang berlaku, bila dipandang perlu di persidangan baik atas kehendaknya sendiri maupun atas permintaan terdakwa atau penasehat hukumnya Pasal 221 KUHAP).

8. Memberikan perintah kepada seseorang untuk mengucapkan sumpah atau janji di luar sidang (223 ayat (1) KUHAP).

Putusan hakim atau putusan pengadilan merupakan aspek penting yang diperlukan untuk menyelesaikan perkara pidana. Dengan demikian dapatlah dikonklusikan lebih jauh bahwasanya putusan hakim disatu pihak berguna bagi terdakwa untuk memperoleh kepastian hukum (rechts zekerheids) tentang statusnya dan sekaligus dapat mempersiapkan 
langkah berikutnya terhadap putusan tersebut dalam artian dapat menerima putusan, melakukan upaya hukum verzet, banding atau kasasi, melakukan grasi dan sebagainya. Sedangkan dilain pihak hakim yang mengadili perkara diharapkan dapat memberikan putusan yang mencerminkan nilai-nilai keadilan dengan memperhatikan sifat baik atau sifat jahat dari terdakwa sehingga putusan yang dijatuhkan setimpal sesuai dengan kesalahannya. $^{4}$

Peranan birokrasi peradilan pidana di pengadilan sangat penting untuk mewujudkan keadilan substansial karena KUHAP menganut model pelayanan (service model) dalam penyelenggaraan peradilan pidana. Berdasarkan model ini untuk terwujudnya kepentingan hukum pencari keadilan diwakilkan sepenuhnya kepada aparat penegak hukum.

Namun saat ini birokrasi peradilan pidana kurang mendapat perhatian dalam penegakan hukum pidana di Indonesia. Ini terlihat masih belum komprehensif pengaturan tentang birokrasi peradilan pidana dalam KUHAP khususnya ketentuan tentang hukum acara persidangan, sedangkan aturan yang ada belum sepenuhnya mengakomodasi kepentingan hukum para pencari keadilan.

Hal ini terlihat adanya penolakan dari pencari keadilan atas cara dan hasil kerja pejabat peradilan dalam memeriksa dan memutus suatu perkara pidana berdasarkan ketentuan di atas. Penolakan tersebut antara lain disebabkan adanya penyelesaian perkara yang berlarut-larut, pelayanan yang bersifat tertutup, kinerja pejabat peradilan yang rendah dan praktik litigasi yang disesuaikan dengan kepentingan pejabat peradilan dan/atau lembaga pengadilan.

Akibat dari cara kerja pejabat peradilan tersebut menimbulkan pelanggaran atas kepentingan hukum pencari keadilan dan menumbuhkembangkan praktik mafia peradilan. Adanya kelemahan ketentuan birokrasi peradilan pidana berdasarkan KUHAP tersebut memberi peluang untuk dimanfaatkan oleh pejabat peradilan untuk memenuhi kepentingan pribadi dan/atau lembaganya.

Lembaga peradilan sebagai penyelenggara tugas negara dalam bidang yudikatif sama seperti lembaga negara di bidang eksekutif dan legislatif juga berkewajiban memberi pelayanan kepada setiap warga negara dan penduduk Indonesia. Dalam kedudukannya sebagai penyelenggara tugas Negara, lembaga peradilan berkewajiban menyelenggarakan pelayanan publik sebagaimana yang telah diamanatkan dalam Undang-Undang Nomor 25

4 Lilik Mulyadi, Putusan Hakim Dalam Hukum Acara Pidana (Teori, Praktik, Teknik Penyusunan Dan Permasalahannya), PT. Citra Aditya Bakti, Bandung,2007, hal. 119 
tahun 2009 tentang Pelayanan Publik. Oleh karena itu pengadilan sebagai lembaga penyelenggara pelayanan publik pada saat ini perlu melakukan pembaharuan terhadap visi, misi, tugas, wewenang dan fungsinya sesuai dengan tuntutan di era reformasi dimana demokrasi di junjung tinggi. Pengadilan harus mengubah dari perannya yang semata-mata sebagai corong undang-undang menjadi pengadilan yang bersifat melayani, mewakili dan mendengarkan kehendak hukum masyarakat.

Pentingnya pelayanan publik sebagai basis birokrasi peradilan pidana, ini mengingat inti pelayanan publik yakni pelayanan prima yang berupa cepat, tepat, akurat, dan berkualitas adalah sejalan dengan asas-asas peradilan cepat, sederhana dan biaya ringan yang mendasari penyelenggaraan peradilan pidana di Indonesia berdasarkan Undang-Undang Nomor 8 Tahun 1981 juncto Undang-Undang Nomor 48 Tahun 2009 tentang Kekuasaan Kehakiman. Selain itu asas-asas pelayanan publik yang berupa antara lain transparansi, akuntabilitas, kondisional, partisifasi, kesamaan hak dan keseimbangan hak dan kewajiban, juga sejalan dengan prinsip-prinsip keadilan berdasarkan Ketuhanan Yang Maha Esa atau keadilan berdasarkan tuntunan Tuhan yakni persamaan, objektifitas, tidak pilih kasih, dan tidak berpihak, yang menjadi tujuan peradilan Indonesia.

Sejak adanya kebijakan satu atap penyelenggaraan peradilan di bawah Mahkamah Agung berdasarkan Undang-Undang Nomor 35 Tahun 1999 juncto Undang-Undang Nomor 14 Tahun 1970 tentang Kehakiman, telah dimulai adanya usaha pembaharuan peradilan. Salah satu dasar hukum pembaharuan peradilan dalam bidang pelayanan publik yaitu adanya Surat Keputusan Ketua Mahkamah Agung Republik Indonesia Nomor 144/KMA/SK/VIII/ 2007 tentang Keterbukaan Informasi di Pengadilan.

Dengan adanya keputusan tersebut setiap pengadilan wajib memberikan akses kepada masyarakat untuk mendapatkan informasi tentang pengadilan yang bersangkutan. Kewajiban pengadilan memberikan akses kepada masyarakat tersebut baru sebatas informasi tentang kegiatan administrasi pengadilan, sedangkan administrasi peradilannya belum. Namun demikian sudah ada beberapa Pengadilan Tinggi yang berusaha atas inisiatifnya sendiri untuk mempraktikkan prinsip-prinsip pelayanan publik dalam proses peradilan pidana.

Dalam rangka transparansi penyelenggaraan peradilan pidana, Pengadilan Tinggi tersebut menerapkan kebijaksanaan dimana dalam penyelenggaraan persidangan perkara pidana menggunakan sarana teknologi informatika sehingga seluruh aktivitas persidangan dapat diakses oleh para pihak maupun masyarakat baik yang berada di dalam maupun di 
luar ruang sidang. Dengan adanya akses publik dalam proses pemeriksaan perkara pidana, diharapkan pemeriksaan perkara oleh pejabat peradilan dilaksanakan secara sungguhsungguh sesuai ketentuan hukum acara persidangan sehingga menghasilkan putusan hakim yang berkualitas (tanpa rekayasa) yang dapat diterima oleh semua pihak.

Penegakan hukum pidana oleh lembaga peradilan sama dengan penegakan hukum pada umumnya yakni merupakan suatu sistem. Sistem tersebut berkaitan dengan sistem hukum yang dikemukakan oleh Friedman meliputi subsistem substansi hukum, subsistem struktur hukum dan subsistem budaya hukum. ${ }^{5}$

Birokrasi dikaitkan dengan bekerjanya hukum memiliki titik sentuh yang bersesuaian, artinya birokrasi harus mampu mengakomodasi sistem hukum, itulah sebabnya Raisul Muttaqienmengintroduksi tentang adanya 3 (tiga) tipe birokrasi sebagai suatu bentuk kesinambungan yang bersifat evolutif, yaitu pra-birokratik (prebureaucratic), birokratik (bureaucratic) dan post-birokratik (postbureaucratic) sebagai perwujudan perkembangan tipe hukum dari hukum represif, otonomos dan responsif. ${ }^{6}$

Penegakan hukum pidana tidak terlepas dari konteks organisasi yang dalam hal ini mempermasalahkan orang, tingkah laku orang-orang, membicarakan fasilitas serta juga membicarakan kultur suatu organisasi. ${ }^{7}$ Sebagai organisasi birokratis lembaga penegak hukum akan selalu berusaha mencari jalan sebaik-baiknya agar pekerjaan lembaga bisa dilaksanakan secara seksama. Untuk itu lembaga didorong mengembangkan suatu kebijakan mengamankan jalannya organisasi, yang oleh Chambliss dan Seidman dirumuskan sebagai "maximizing rewards and minimizing strains on the organization".

Penegakan hukum pidana tidak dapat dilakukan secara total sebab para penegak hukum dibatasi secara ketat oleh aturan hukum acara pidana dan hukum pidana substantif. Penegakan hukum pidana membutuhkan kinerja aparat penegak hukum bersifat progresifyaitu menegakkan hukum pidana dalam rangka mewujudkan keadilan, kesejahteraan dan kepentingan rakyat. Supremacy of law bukan diterjemahkan sebagai supremasi undang-undang, melainkan supremacy of justice.

${ }^{5}$ Friedmandalam M. Yahya Harahap, Pembahasan Permasalahan Dan Penerapan KUHAP Pemeriksaan Sidang Pengadilan, Banding, Kasasi Dan Peninjauan Kembali, Sinar Grafika, Jakarta, 2006, hal. 346

${ }^{6}$ Raisul Muttaqien, Hukum Responsif, Nusamedia, Bandung, 2008. hal.27

${ }^{7}$ Satjipto Rahardjo, Penegakan Hukum Suatu Tinjauan Sosiologis, Genta Publishing, Yogyakarta, 2009, hal. 15.

${ }^{8}$ Satjipto Rahardjo, Masalah Penegakan Hukum Suatu Tinjauan Sosiologis. BPHN. Jakarta. 1997,hal. 22 
Cara kerja seperti itu sejalan dengan tuntutan cara kerja aparat peradilan yang diamanatkan oleh Undang-Undang Nomor 48 Tahun 2009 tentang Kekuasaan Kehakiman, Pasal 5 ayat (1) bahwa hakim wajib menggali, mengikuti, dan memahami nilai-nilai hukum dan rasa keadilan yang hidup dalam masyarakat. Cara kerja seperti itu merupakan perwujudan birokrasi peradilan pidana berbasis pelayanan publik yang diwujudkan dalam bentuk pelayanan prima dan pelayanan sepenuh hati.

\section{B. Perumusan Masalah}

Adapun pertanyaan-pertanyaan penelitian yang memfokuskan permasalahan di atas adalah:

1. Bagaimanakah penyelesaian perkara pidana dalam proses administrasi perkara pidana di Pengadilan Tinggi Jambi?

2. Bagaimanakah Kendala yang dihadapi dalam penyelesaian perkara pidana dalam proses administrasi perkara pidana di Pengadilan Tinggi Jambi?

\section{Metode Penelitian}

\section{Metode Pendekatan}

Berdasarkan perumusan masalah dan tujuan penelitian, maka pendekatan yang dilakukan dalam penelitian ini adalah "Empiris". Yakni mempelajari peraturan perundang-undangan yang ada kemudian dihubungkan dengan pelaksanaannya dilapangan atau dalam kehidupan dalam masyarakat.

\section{Spesifikasi Penelitian}

Spesifikasi penelitian ini bersifat deskriptif analitis, dimana dalam penulisan ini bermaksud untuk memberikan gambaran dan uraian mengenai ketentuan perundang-undangan yang mengatur mengenai penyelesaian perkara pidana dalam proses administrasi perkara pidana di Pengadilan Tinggi Jambi.

Dari semua data yang diperoleh baik data primer maupun data sekunder yang telah dikumpulkan, diseleksi dan data tersebut diklasifikasikan. Setelah diklasifikasikan kemudian dilakukan analisis secara kualitatif kemudian hasilnya diuraikan secara deskriptif. Data yang terkumpul diseleksi dan diklasifikasi sesuai dengan karakteristiknya, lalu dilakukan analisis secara kualitatif. Interprestasi hasil penelitian disajikan secara deskriptif. 


\section{Analisis yuridis penyelesaian perkara pdana dalam proses administrasi perkara pidana di pengadilan tinggi Jambi}

1. Penyelesaian perkara pidana dalam proses administrasi perkara pidana di Pengadilan Tinggi Jambi

Sebelum sampai pada penyelesaian perkara pidana dalam proses admisnistrasi perkara pidana di Pengadilan Tinggi, terlebih dahulu penulis ketengahkan tujuan peradilan pidana. Tujuan peradilan pidana adalah untuk memutuskan apakah seseorang bersalah atau tidak, peradilan pidana dilakukan dengan prosedur yang tertuang dalam peraturan perundang-undangan yang mencakup semua batas-batas konstitusional dan berakhir pada proses pemeriksaan di pengadilan.

Mekanisme pemeriksaan perkara pidana di Pengadilan Tinggi berdasarkan beberapa tahap persidangan. Tahapan tersebut adalah sebagai berikut:

1. Dilaksanakan di Pengadilan Tinggi Negeri (PTN)

2. Penahanan dilakukan oleh hakim Pengadilan Tinggi (PT) selama 30 hari dan 60 hari jika ada perpanjangan hakim Pengadilan Tinggi mengajukan ke Ketua Pengadilan Tinggi. (Pasal 27 KUHAP)

3. Hakim yang akan memeriksa di Pengadilan Tinggi atas perkara yang diajukan banding harus berbeda.

4. Pemeriksaan ulang fakta-fakta seperti dalam tingkat pertama / Pengadilan Negeri (PN). Apapun alasan dapat digunakan unttk mengajukan banding, karena pemeriksaan di PTN adalah judex factie (perkara diperiksa ulang).

5. Terdakwa/Penuntut Umum berhak meminta banding atas putusan pengadilan tingkat pertama kecuali atas putusan bebas, lepas dari segala tuntutan, dan putusan dalam keadaan acara cepat (kecuali pidana penjara). (Pasal 67 KUHAP)

6. Diajukan paling lambat 7 hari setelah putusan atau setelah putusan diberitahukan kepada terdakwa yang tidak hadir pada saat pembacaan putusan oleh hakim.

7. Terdakwa atau pihak yang berhak mengajukan banding dapat membuat memori banding (alasan banding) yang menjadi dasar permohonan banding sedangkan pihak lawan membuat kontra memori. Kedua memori tersebut diajukan sebelum pemeriksaan banding. 
8. Permohonan banding dapat dicabut dan tidak bisa diajukan kembali sebelum putusan banding. Apabila permohonan banding sudah sampai pada proses persidangan maka biaya persidangan dibayar oleh pihak yang mencabut permohonan banding.

9. Putusan banding

a. Menguatkan putusan Pengadilan Negeri secara murni, dengan tambahan pertimbangan atau pertimbangan lain.

b. Mengubah putusan Pengadilan Negeri (termasuk alasan penjatuhan putusan) yaitu perubahan kualifikasi tindak pidana, perubahan barang bukti, dan perubahan pemidanaan.

c. Membatalkan putusan Pengadilan Negeri dan mengadakan putusan sendiri (Ex. dari putusan pemidanaan ke putusan bebas)

Menurut sistem pemeriksaan di sidang pengadilan yang dipimpin oleh hakim, hakim itu harus bersifat aktif, hakim harus bertanya dan memberi kesempatan kepada pihak terdakwa yang diwakili oleh penasehat hukumnya untuk bertanya kepada saksisaksi, begitu pula kepada penuntut umum. Semua ini dengan maksud menemukan kebenaran materil. Hakimlah yang bertanggungjawab atas segala yang diputuskannya. ${ }^{9}$

Untuk menjamin hal tersebut maka hakim diberi kekuasaan yang bebas dan mandiri agar putusan-putusannya tidak mudah diintevensi oleh kekuatan diluar pengadilan seperti penguasa dan kekuatan lainnya dalam masyarakat seperti kekuatan politik dan ekonomi. Hal ini dijamin oleh Undang-Undang Dasar (UUD) 1945 dan peraturan perundangundangan yang berlaku positif di Indonesia, antara lain Undang-undang Nomor 48 Tahun 2009 tentang Kekuasaan Kehakiman yang merupakan perubahan terhadap Undang-undang Nomor 4 Tahun 2004 dan Undang-undang tentang Mahkamah Agung Republik Indonesia Nomor 3 Tahun 2009 sebagai perubahan kedua atas Undang-undang Nomor 14 Tahun 1985.

Panitera Pengadilan Tinggi Jambi, memandang bahwa tugas pengadilan adalah untuk membuat suatu putusan yang akan mencegah konflik dan untuk mewujudkan tugas tersebut, pengadilan membutuhkan tiga masukan, yaitu:

${ }^{9}$ Jalaluddin, Hakim Pengadilan Tinggi Jambi, wawancara tanggal 1 April 2014 
1. Pengadilan membutuhkan analisis tentang hubungan sebab akibat, antara hal-hal yang diputus dengan kemungkinan-kemungkinan yang akan diderita dari akibat putusan tersebut.

2. Pengadilan membutuhkan evaluasi tuntutan-tuntutan yang saling bertentangan dan mengantisipasi efek-efek dari suatu putusan.

3. Pengadilan membutuhkan suatu kemauan para pihak untuk menggunakan pengadilan untuk menyelesaikan konflik.

Seorang Hakim Pengadilan Tinggi Jambi, mengakui Putusan hakim itu lahir bukan berdasarkan fakta-fakta yang terungkap dalam persidangan berdasarkan ketentuan peraturan perundang-undangan saja tetapi kombinasi antara fakta-fakta yang terungkap dalam persidangan berdasarkan ketentuan peraturan perundang-undangan tersebut dengan perilaku atau moralitas dari hakim itu sendiri. Oleh karena itulah ia menyatakan bahwa hukum buatan hakim alias putusan hakim sebagai salah satu dari realitas-realitas kehidupan yang ada. Jadi, hukum ialah perilaku dan dalam hal ini ialah perilaku hakim tertentu yang belum tentu persis sama dengan perilaku hukum hakim lain, meskipun menghadapi kasus yang sejenis dan menggunakan ketentuan hukum yang sama.

Ada dua faktor utama yang mempengaruhi putusan hakim, yakni:

1. Faktor internal adalah segala sesuatu yang mempengaruhi kemandirian hakim dalam menjalankan tugas dan wewenangnya yang datangnya dari dalam diri hakim itu sendiri yaitu yang berkaitan dengan Sumber Daya Manusia (SDM), mulai dari rekrutmen/seleksi untuk diangkat menjadi hakim, pendidikan hakim dan kesejahteraan hakim.

2. Faktor eksternal yakni segala sesuatu yang mempengaruhi putusan hakim yang berasal dari luar diri hakim, antara lain:

a. Peraturan perundang-undangan.

b. Adanya intervensi terhadap proses peradilan.

c. Hubungan hakim dengan penegak hukum lain.

d. Adanya berbagai tekanan.

e. Faktor kesadaran hukum, dan

f. Faktor sistem pemerintahan.

Panitera Pengadilan Tinggi Jambi, merinci lagi faktor internal yang mempengaruhi putusan hakim tinggi yaitu: 
a. Faktor subjektif yakni cara pandang atau sikap seorang hakim dalam memandang suatu perkara pidana, yang terdiri dari:

1. Sikap perilaku yang apriori.

Adanya sikap seorang hakim yang sejak semula sudah menganggap bahwa terdakwa yang diperiksa dan diadili adalah orang yang memang telah bersalah sehingga harus dipidana.

2. Sikap perilaku emosional.

Putusan pengadilan akan dipengaruhi perangai seorang hakim. Hakim yang mempunyai perangai mudah tersinggung akan berbeda dengan perangai seorang hakim yang tidak mudah tersinggung. Demikian pula dengan putusan dari seorang hakim yang mudah marah dan pendendam akan berbeda dengan putusan hakim yang sabar.

3. Sikap sombong atau congkak atas kekuasaannya.

Sikap lain yang mempengaruhi suatu putusan adalah "kecongkakan kekuasaan". Di sini hakim merasa dirinya berkuasa dan pintar, melebihi orang lain (jaksa, pembela apa lagi terdakwa).

4. Moral.

Amat berpengaruh adalah moral seorang hakim karena bagaimanapun juga pribadi seorang hakim diliputi oleh tingkah laku yang didasari oleh moral pribadi hakim tersebut terutama pada saat memeriksa serta memutuskan suatu perkara.

b. Faktor Objektif yaitu faktor yang berasal dari dalam diri hakim yang dipengaruhi oleh:

1. Latar belakang budaya.

Kebudayaan, agama, pendidikan seorang hakim tentu ikut mempengaruhi suatu putusan hakim. Meskipun latar balakang hidup budaya bukan merupakan faktor yang menentukan, tetapi faktor ini setidak-tidaknya ikut mempengaruhi hakim dalam mengambil suatu keputusan.

\section{Profesionalisme}

Kecerdasan serta profesionalisme seorang hakim ikut mempengaruhi keputusannya. Perbedaan suatu putusan pengadilan sering dipengaruhi oleh profesionalisme hakim tersebut. 
Syarat utama bagi keputusan hakim itu adalah bahwa keputusan itu haruslah beralasan sehingga dapat dipertanggungjawabkan, bukan saja terhadap yang berkepentingan langsung, yaitu penuntut umum dan si terdakwa tetapi juga terhadap masyarakat umumnya. Dengan keputusannya itu hakim harus menunjukkan bahwa ia tidak mengambil keputusan dengan sewenang-wenang, bahwa peradilan yang ditugaskan kepadanya sebagai anggota dari kekuasaan kehakiman, selalu dijunjung tinggi dan dipelihara sebaik-baiknya, sehingga kepercayaan umum akan penyelenggaraan peradilan yang layak tidak akan sia-sia belaka, andaikata hakim tidak menemukan hukum tertulis, hakim wajib menggali hukum tidak tertulis untuk memutuskan berdasarkan hukum

Sejak berlakunya Undang-Undang Nomor 8 Tahun 1981 tentang KUHAP telah menimbulkan perubahan fundamental baik secara konsepsional maupun implemental terhadap tata cara penyelesaian perkara pidana. Adanya perubahan sistem peradilan yang dianut KUHAP menuntut adanya perubahan cara berpikir, bersikap dan bertindak (kultur) pejabat peradilan. Hal ini mengingat efektivitas suatu undang-undang sangat ditentukan oleh para penegak hukumnya.

Apabila terdakwa dan/atau JPU menolak putusan hakim atau mengajukan banding, maka seluruh berkas perkara tersebut diserahkan oleh panitera Pengadilan Negeri (PN) kepada kepaniteraan Pengadilan Tinggi (PT) untuk diperiksa dalam tingkat banding. Persidangan perkara banding di Pengadilan Tinggi (PT)pada umumnya dilakukan dengan cara hanya mempelajari berkas perkara, sehingga tidak pernah menggelar perkara atau menyidangkan kembali untuk mendengarkan keterangan terdakwa, saksi atau JPU.

Adapun administrasi penyelesaian perkara pidana di Pengadilan Tinggi Jambi menurut Hakim Pengadilan Tinggi Jambi mengatakan bahwa pengaturan administrasi penyelesaian perkara pidana harus sesuai dengan Surat Keputusan Ketua Mahkamah Agung Republik Indonesia Nomor: 026/KMA/SK/II/2012 tentang Standar Pelayanan Peradilan tertanggal 9 Februari 2012.

Penjelasan administrasi penyelesaian perkara pidana yang masuk ke Pengadilan Tinggi Jambi sebagai berikut:

a. Terdakwa/Penasihat Hukumnya dapat mengajukan Permohonan bandingdalam waktu 7 (tujuh) hari sesudah putusan dijatuhkan, atau setelah putusandiberitahukan kepada terdakwa yang tidak hadir dalam pengucapanputusan. Dalam hal jangka waktu tersebut terlampaui maka 
permohonanbanding tersebut akan ditolak oleh pengadilan dengan membuat suratketerangan permohonan banding.

b. Terhadap Permohonan banding yang telah memenuhi prosedur dan waktuyang ditetapkan, Panitera harus membuatkan akta pemyataan banding yangditandatangani oleh Panitera dan pemohon banding, serta diberitahukankepada termohon banding.

c. Setiap penerimaan permohonan banding yang diajukan dalam hal terdakwaada dalam tahanan, Ketua Pengadilan Negeri harus melaporkan padaPengadilan Tinggi tentang permohonan tersebut paling lambat 2 (dua) hari.

d. Sebelum berkas perkara dikirim ke Pengadilan Tinggi, pemohon dantermohon banding wajib diberi kesempatan untuk mempelajari berkasperkara selama 7 (tujuh) hari.

e. Selama perkara banding belum diputus oleh Pengadilan Tinggi, permohonanbanding dapat dicabut sewaktu-waktu, dan dalam hal sudah dicabut,pemohon tidak boleh mengajukan permohonan banding lagi, kecuali masihdalam tenggang waktu masa pengajuan banding.

f. Dalam hal perkara telah diputus oleh pengadilan banding, salinan putusandikirim kepada Pengadilan Negeri untuk diberitahukan kepada terdakwadan Penuntut Umum, yang untuk itu Panitera membuat akta pemberitahuanputusan dalam waktu paling lama 2 (dua) hari. ${ }^{10}$

Jadi dapat disimpulkan bahwa dalam penyelesaian administrasi perkara yang ada di Pengadilan Tinggi Jambi saat ini telah berjalan sebagaimana aturan yang dikeluarkan oleh Mahkamah Agung dikuatkan dengan Surat Keputusan Ketua Mahkamah Agung Republik Indonesia. Jika penyelesaian perkara tidak sesuai dengan ketentuan yang berlaku Hakim dapat dikenakan sanksi dalam pelaksanaan tugasnya.

2. Kendala yang dihadapi dalam penyelesaian perkara pidana dalam proses administrasi perkara pidana di Pengadilan Tinggi Jambi.

Kendala yang dihadapi oleh Pengadilan Tinggi Jambi dalam Proses penyelesaian perkara pidana disebabkan oleh 2 (dua) faktor, yaitu faktor internal dan faktor eksternal.

Selanjutnya Ketua Pengadilan Tinggi Jambi menjelaskan sebagai berikut:

${ }^{10}$ Jalaluddin, Hakim Pengadilan Tinggi Jambi, wawancara tanggal 1 April 2013 
1. Faktor Internal

a. Banyaknya jumlah perkara yang masuk ke Pengadilan Tinggi Jambi sehingga menyulitkan dalam menetapkan hari sidang.

b. Kurangnya sumber daya manusia dalam hal ini Hakim di Pengadilan Tinggi Jambi masih kurang.

c. Antara jumlah perkara dengan jumlah Hakim di Pengadilan Tinggi Jambi tidak sebanding

d. Kurangnya sarana dan prasaran, misalnya ruang sidang

e. Adanya beberapa Hakim yang tidak hanya menanganai perkara pidana saja melainkan merangkap menangani perkara perdata

\section{Faktor Eksternal}

a. Lambatnya perkara masuk ke Pengadilan Tinggi Jambi karena jarak antar Pengadilan yang sangat jauh.

b. Kurang Pro aktifnya para advokat dalam membantu terhadap administrasi perkara di Pengadilan Tinggi Jambi.

Selanjutnya dalam proses penyelesaian perkara pidana, kinerja pengadilan dipengaruhi oleh beberapa faktor, antara lain yakni:

\section{Hukum Acara Pidana}

Hakim/Majelis Hakim dalam memeriksa dan memutus segala jenis perkara pidana mempergunakan Hukum Acara Pidana.

2. Administrasi Perkara

Suatu perkara perdata sejak dimasukkan ke pengadilan telah melalui proses administrasi hukum dan didaftarkan kepada petugas. Selanjutnya berkas ini berpindah ke beberapa petugas hingga akhirnya sampai ketangan Majelis Hakim untuk diperiksa, diadili dan diputuskan.

3. Budaya Pengadilan

Budaya pengadilan dibentuk oleh kode etik profesi Hakim. Kinerja pengadilan dapat diartikan sebagai kemampuan pengadilan (hakim) menegakkan hukum dan keadilan berdasarkan Ketuhanan Yang Maha Esa sebagaimana dirumuskan dalam uraian tugas masing-masing.

Keberhasilan melaksanakan tugas yang diamanatkan undang-undang tersebut merupakan penilaian terhadapkinerja pengadilan itu sendiri. Salah satu tugaspengadilan adalah menyelesaikan perkara yangdiajukan ke pengadilan, baik berupa perkara yang 
termasuk di dalamnyapersoalan yang berkaitan dengan dinamika hukum. Dalam proses penyelesaian perkara pidana, kinerja pengadilan mengacu kepada Hukum Acara Pidana.

\section{E. Kesimpulan}

1. Bahwa penyelesaian administrasi perkara yang ada di Pengadilan Tinggi Jambi saat ini telah berjalan sebagaimana aturan yang dikeluarkan oleh Mahkamah Agung dikuatkan dengan Surat Keputusan Ketua Mahkamah Agung Republik Indonesia. Jika penyelesaian perkara tidak sesuai dengan ketentuan yang berlaku Hakim dapat dikenakan sanksi dalam pelaksanaan tugasnya.

2. Bahwa kendala yang dihadapi adalah Hukum Acara Pidana, Administrasi Perkara dan budaya Pengadilan. Selain itu lambatnya penyelesaian administrasi perkara dikarenakan letak Pengadilan yang jauh di daerah, sehingga pengiriman administrasi untuk perkara banding ke Pengadilan Tinggi Jambi membutuhkan waktu lebih lama.

\section{F. Rekomendasi}

1. Agar penyelesaian admisnistrasi perkara dapat berjalan maksimal maka diperlukan penambahan sumberdaya manusia yang ada di Pengadilan Tinggi berupa penambahan jumlah Hakim yang ada, penambagan sarana dan prasarana, serta penambahan dana atau anggaran bagi proses persidangan pada tingkat banding.

2. Agar masyarakat dapat mengawasi proses persidangan dan perkembangan perkara pada tingkat banding diharapkan adanya akses melalui wibesite terkait dengan perkembangan perkara yang telah, sedang dan diputuskan oleh hakim pada tingkat banding.

\section{G.Daftar Pustaka}

Yesmil Anwar dan Adang, System Peradilan Pidana (Konsep, Komponen dan Pelaksanaannya Dalam Penegakkan Hukum Di Indonesia), Widya Padjadjaran, Bandung, 2009

Waluyadi, Pengetahuan Dasar Hukum Acara Pidana(Sebuah Catatan Khusus), Mandar Maju, Bandung, 1999

Lilik Mulyadi, Hukum Acara Pidana (Suatu Tinjauan Khusus Terhadap Surat Dakwaan, Eksepsi Dan Putusan Peradilan), PT. Citra Aditya Bakti, Bandung, 2002

Friedmandalam M. Yahya Harahap, Pembahasan Permasalahan Dan Penerapan KUHAP Pemeriksaan Sidang Pengadilan, Banding, Kasasi Dan Peninjauan Kembali, Sinar Grafika, Jakarta, 2006

Raisul Muttaqien, Hukum Responsif, Nusamedia, Bandung, 2008 
Satjipto Rahardjo, Penegakan Hukum Suatu Tinjauan Sosiologis, Genta Publishing, Yogyakarta, 2009

Satjipto Rahardjo, Masalah Penegakan Hukum Suatu Tinjauan Sosiologis. BPHN. Jakarta. 1997 